\title{
INDIUM EXTRACTION FROM LCD SCREENS
}

\author{
Adjanara P. Gabriel *, Bruna Baggio Giordani, Angela Kasper and Hugo M. Veit
}

PPGE3M - Materials Engineering Department, Federal University of Rio Grande do Sul - UFRGS. Av. Bento Gonçalves, 9500, Setor IV, Prédio 43426, CEP: 91501-970, Porto Alegre, Brazil

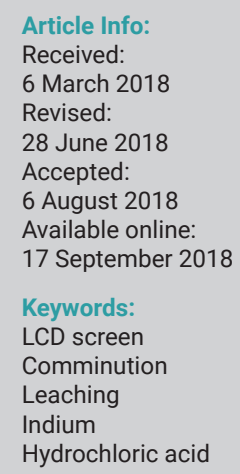

\begin{abstract}
Liquid crystal display (LCD) screens are present in a variety of electronic devices including televisions, computers, cell phones, global positioning system (GPS) devices, and others. On a vitreous layer of their inner surface these screens contain the chemical element indium. The presence of this element, considered a critical raw material due to its economic importance and scarce availability, renders the recycling of these screens increasingly attractive. The present study therefore was undertaken with the aim of extracting indium present in LCD screens. Damaged or obsolete monitors with LCD screens were collected and dismantled manually to remove the glass layer containing indium, and subsequently, the glass layer was ground in a ball mill. After grinding, leaching tests for indium extraction were performed. Hydrochloric acid $(\mathrm{HCl})$, at different temperatures and concentrations, was tested as a leaching agent at solid/liquid ratios of $1 / 100$ and $1 / 10$. The results obtained reveal the possibility of extracting indium, with the best result being obtained with $\mathrm{HCl} 6 \mathrm{M}, 60^{\circ} \mathrm{C}, \mathrm{s} / \mathrm{I}$ ratio $1 / 100$, with $298 \mathrm{mg} \mathrm{ln} / \mathrm{kg}$.
\end{abstract}

\section{INTRODUCTION}

The electrical and electronic equipment (EEE) sector is one of the fastest growing in the world. However, due to rapid and constant innovation EEE tend to rapidly become obsolete. Once these products become obsolete or are no longer functional, they are considered as waste electrical and electronic products (WEEE). The main WEEE products include TVs, computers, cell phones and home appliances. Recycling of WEEE products involves a wide range of techniques and processes, largely aimed at the recovery of different materials, particularly metals (Gramatyka P. et al., 2007; Schaik A.V. and Reuter M.A., 2010; Wang X., Lu X. and Zhang S., 2013).

Television and computer monitors are characterized by a complex structure consisting mainly of glass, polymers, various metals and printed circuit boards, all of which add value to these materials (Gabriel et al., 2014). In addition, these wastes may contain precious metals such as gold and silver, and also indium, which are suitable for recovery in view of their potential value.

Since their invention, LCDs (Figure 1) have become one of the main types of screens used in televisions, computers and cell phones. This type of equipment has a short life cycle and contains considerable quantities of valuable materials.

The composition of LCDs comprises materials such as polymers, metals and ceramics (glass), thus rendering the recycling of this type of product extremely complex. Among the metals present, indium (In), a rare and highly versatile metal used in LCDs in the form of indium-tin oxide (ITO) can be detected.

ITO is a mixture of indium (III) oxide and tin (IV) oxide (indium-tin oxide) with a typical composition of $90 \mathrm{wt} \%$ In203 and $10 \mathrm{wt} \% \mathrm{SnO}_{2}$ in LCDs (Swain et al., 2016). ITO is a transparent and conductive material frequently used in the manufacture of thin-film transistors (TFT) used in liquid crystal displays (Virolainen et al., 2014; Chou and Huang, 2009).

The basic structure of the LCD screen as described by Juchneski et al. (2013) is illustrated in Figure 2. Item 1 represents the vertically polarizing film; item 2 the layer of glass with ITO; item 3 the liquid crystal; item 4 another glass layer with ITO; item 5 is the horizontal polarizing film; and item 6 the diffuser sheet.

Generally, the LCD panel consists of a glass substrate and a backlight module. The surface of the glass substrate is attached to a polarizing film, and the inner side is coated with functional films (ITO). As major functional units of LCD, the glass substrate accounts for $40-50 \mathrm{wt} \%$, and the backlight module for another $35-40 \mathrm{wt} \%$ (including light guide plate and backlight). The light guide plate consists of polymethyl methacrylate (PMMA), polyethylene terephthalate (PET) or polycarbonate $(P C)$ and a small printed circuit board (PCB) (Fisher, 2004). A cold cathode fluorescent lamp (CCFL) used as a backlight is parallelly 


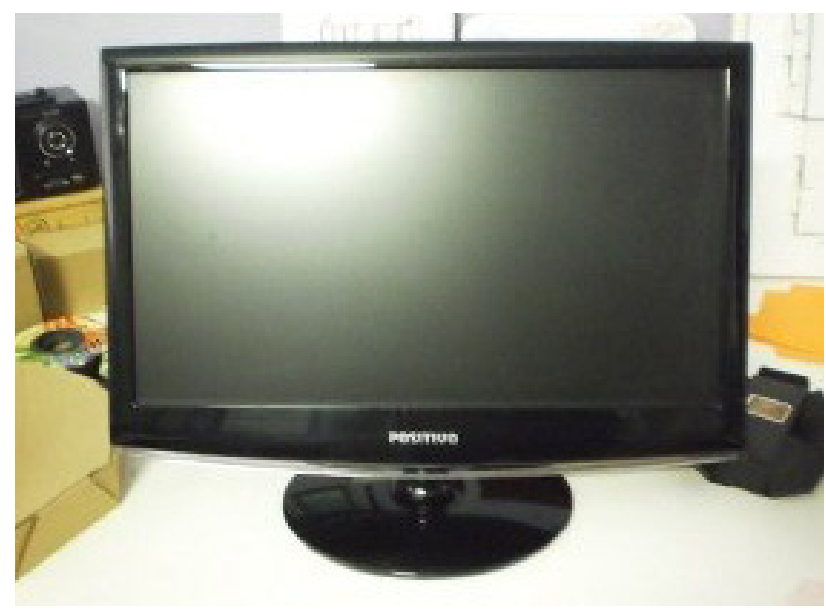

FIGURE 1: Image of a monitor with LCD screen.

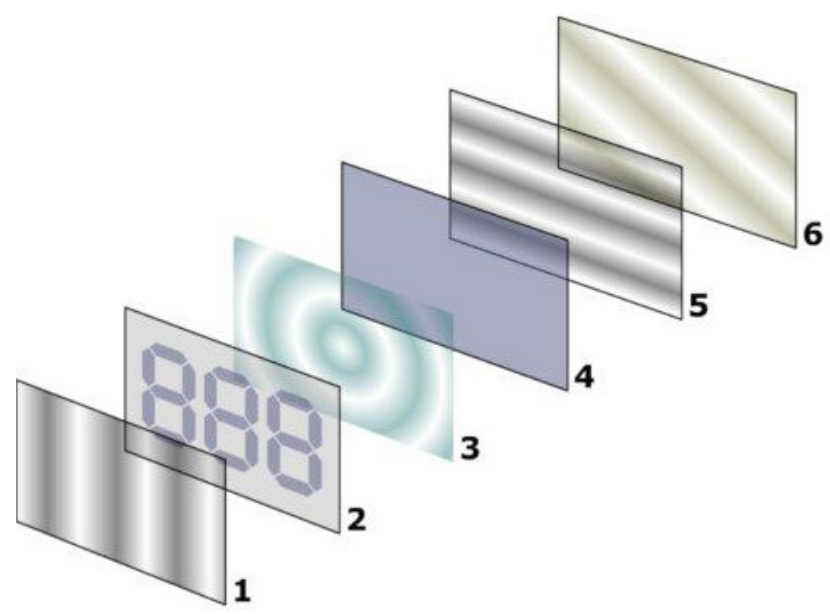

FIGURE 2: Structure of an LCD screen. loaded along one or both sides. A metal frame (made of steel or aluminum) is usually mounted over the glass substrate and backlight module to protect the structure ( $\mathrm{Li}$ et al., 2009).

Leaching is a widely used method in the extraction and recovery of metals from electrical and electronic waste (Bernardes and Veit, 2015). This process may also represent an effective method for use in the extraction of indium present in monitors.

Indium is a fundamental element in electronic devices, thus underlining the importance of developing and improving new recycling methods. Accordingly, the present study was aimed at extracting indium from LCD screens using hydrochloric acid and testing variations of the acid concentration, leaching temperature and solid/liquid ratio.

The variations applied in leaching tests (temperature, concentration and solid/liquid ratio) highlight the innovative nature of this work, which differs considerably from other studies reported in the literature. Several articles have reported the use of a series of different leaching agents or concentrations, others varying temperatures; however, to date no previous studies have been conducted to compare all these parameters. The only comparison available was performed by Yang et al. (2013) who compared a series of different concentrations.

\section{MATERIALS AND METHODS}

\subsection{Manual Disassembly}

LCD monitors of different brands and year of manufacture were initially collected. The monitors were then weighed and manually disassembled to segregate the components.

Monitors were essentially separated into four parts: liquid crystal screen, polymer sheets, polymer frames and printed circuit boards, as shown in Figure 3.

For the purpose of the present study the screens alone were used, whilst all remaining components were forwarded to recycling companies.

\subsection{Comminution of the screens}

The glass layers were manually fragmented into smaller pieces ( 3 to $5 \mathrm{~cm}$ ), before milling the screens for 6 hours in a Servitech model CT-242 alumina ball mill. Particle size is of particular importance with an aim to improving the leaching process, because the larger the surface area the better the contact between the material and the leaching agent. Figure 4 shows the ball mill with the comminuted screens.

\subsection{Chemical Characterization}

X-ray fluorescence (XRF) analysis (Thermo Scientific Niton XL3t portable analyzer) was used to verify the pres-

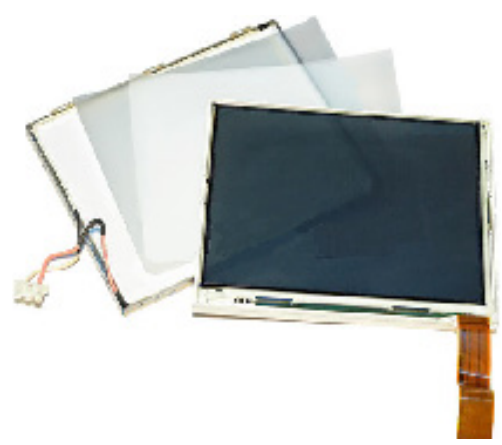

(a)

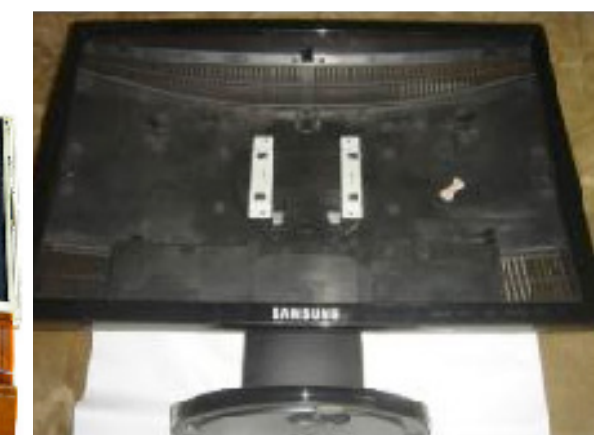

(b)

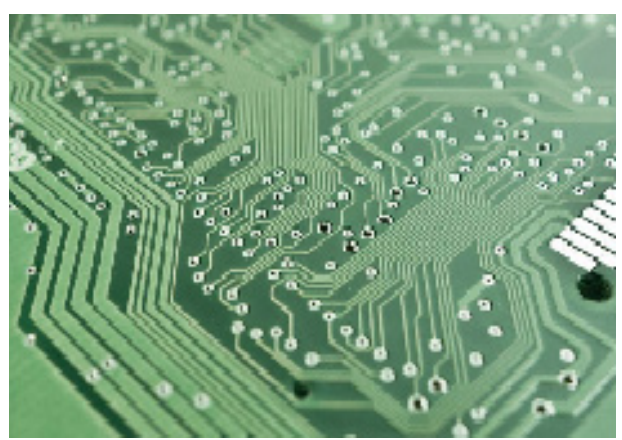

(c)

FIGURE 3: Disassembled LCD monitors: (a) screen and polymer sheets, (b) polymer frames, (c) printed circuit board. 
ence of indium in the powder obtained by milling. To obtain a better result, the powder obtained from milling was sieved in a mesh (\#325). The particle size was selected on the basis of data from the literature (Dias et al., 2018 and M. del C. Ruiz et al., 2004).

\subsection{Leaching}

Samples of the powder obtained from the milled screens were separated for use in the leaching tests. For each test, specific amounts of materials were used, as shown in Table 1.

For this step an acidic leachate was used (hydrochloric acid) at a concentration of $38 \%$ and subsequent dilution with deionized water until the desired molarity was reached, as shown in Table 1.

The concentrations of metals obtained in the leaching tests were determined by means of an ICP OES, Agilent model 5110 . In the ICP-OES analyses, a calibration curve was made between $0.02 \mathrm{ppm}$ and $6 \mathrm{ppm}$ with linearity of $99.9 \%$ from a standard solution of In with $100 \mathrm{ppm}$ of brand SpecSol. The results presented correspond to an average of three wavelengths $(325.609,230.606$ and 410.176$)$.

\section{RESULTS AND DISCUSSION}

\subsection{Manual Disassembling}

Table 2 shows the total weight of two monitors and the weight of the screens.

\subsection{Comminution of the screens}

Figure 5 illustrates the material obtained after 6 hours of milling. The screens containing the layer of ITO were milled repeatedly through collisions between the balls or the balls and the mill container, thus facilitating the obtaining of extremely small particles.

\subsection{Chemical characterization of screens}

Table 3 describes the main components obtained by the FRX test, in powder after comminution. The main elements detected are typical of the standard formulation used for glass production, although, additionally, indium and tin were also detected.

Values obtained for indium and tin in the FRX were very low, indicating the presence of minimal quantities of these elements in the screens.

\subsection{Results of Screen leaching}

The results of the leaching tests are presented in Table

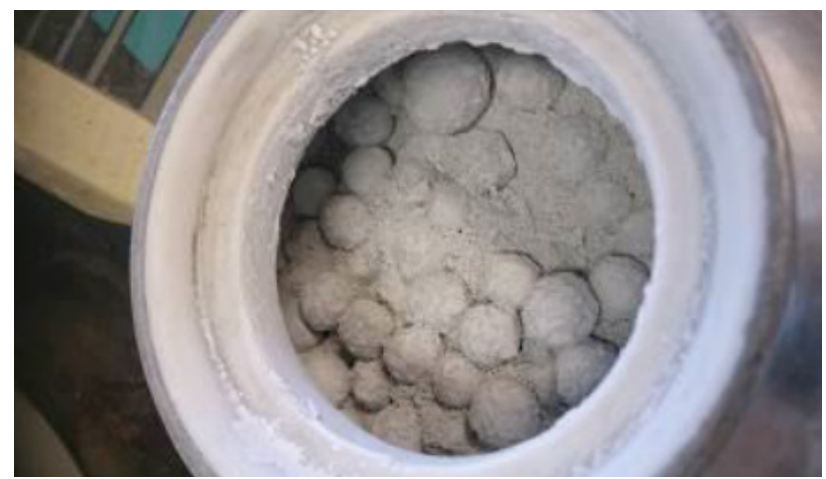

FIGURE 4: Material inside the ball mill container.

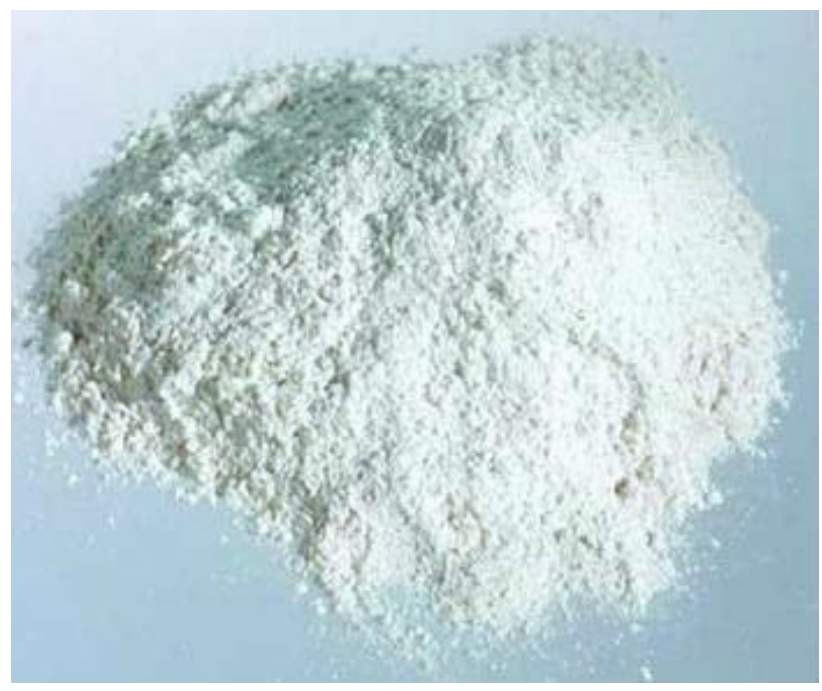

FIGURE 5: Material obtained after milling.

4. The best result was obtained using $6 \mathrm{M} \mathrm{HCl}$ at a temperature of $60^{\circ} \mathrm{C}$ and a solid/liquid ratio $1 / 100$, with $298 \mathrm{mg}$ $\mathrm{In} / \mathrm{kg}$, although in general the results were all comparable. On taking into account the economic and environmental aspects, the most interesting result was obtained at the lowest acid concentration $(1 \mathrm{M})$ and solid/liquid ratio of $1 / 100$ and $60^{\circ} \mathrm{C}$, with $272 \mathrm{mg} \mathrm{ln} / \mathrm{kg}$.

Using $5 \mathrm{~g}$ of material, no significant differences were observed when comparing temperature and concentration; moreover, molarity of the acid scarcely influenced the results obtained. However, using both low and high concentrations, better results were yielded when using $0.5 \mathrm{~g}$ material.

Yang et al. (2013) studied ITO leaching using a series of

TABLE 1: Leaching tests parameters with hydrochloric acid.

\begin{tabular}{|c|c|c|c|c|}
\hline $\begin{array}{l}\text { Concentration of } \mathrm{HCl} \\
(\mathrm{M})\end{array}$ & $\begin{array}{l}\text { Leaching Time } \\
\text { (hours) }\end{array}$ & $\begin{array}{c}\text { Temperature } \\
\left({ }^{\circ} \mathrm{C}\right)\end{array}$ & $\begin{array}{l}\text { Amount of Milled Screens } \\
(\mathrm{g})\end{array}$ & $\begin{array}{l}\text { Volume of } \mathrm{HCl} \\
(\mathrm{ml})\end{array}$ \\
\hline \multirow{2}{*}{1} & \multirow{2}{*}{4} & 28 & 0.5 and 5 & 50 \\
\hline & & 60 & 0.5 and 5 & 50 \\
\hline \multirow{2}{*}{4} & \multirow{2}{*}{4} & 28 & 0.5 and 5 & 50 \\
\hline & & 60 & 0.5 and 5 & 50 \\
\hline \multirow{2}{*}{6} & \multirow{2}{*}{4} & 28 & 0.5 and 5 & 50 \\
\hline & & 60 & 0.5 and 5 & 50 \\
\hline
\end{tabular}


TABLE 2: Mass of samples collected.

\begin{tabular}{c|ccc:c} 
Brand & $\begin{array}{c}\text { Year of } \\
\text { manufacture }\end{array}$ & $\begin{array}{c}\text { Monitor total } \\
\text { weight } \mathbf{( k g})\end{array}$ & $\begin{array}{c}\text { Screen } \\
\text { weight } \mathbf{( k g})\end{array}$ \\
\hline A & 2005 & 4.3 & 0.46 \\
\hline B & 2006 & 4.0 & 0.37 \\
\hline
\end{tabular}

TABLE 3: Components found by FRX in the screens

\begin{tabular}{c|c} 
Component & Sample (\%) \\
\hline $\mathrm{SiO}_{2}$ & $68.58 \pm 4.34$ \\
$\mathrm{Al}_{2} \mathrm{O}_{3}$ & $12.93 \pm 0.82$ \\
$\mathrm{CaO}^{2}$ & $7.36 \pm 0.49$ \\
$\mathrm{As}_{2} \mathrm{O}_{3}$ & $1.45 \pm 0.22$ \\
$\mathrm{SrO}$ & $1.13 \pm 0.17$ \\
$\mathrm{~K}_{2} \mathrm{O}$ & $0.41 \pm 0.38$ \\
$\mathrm{SnO}_{2}$ & $0.04 \pm 0.02$ \\
\hline $\mathrm{InO}_{2}$ & $0.02 \pm 0.02$ \\
\hline & \\
\hline
\end{tabular}

TABLE 4: Results obtained in the leaching test with $\mathrm{HCl}$ to samples after 6 hours of milling.

\begin{tabular}{|c|c|c|c|}
\hline Concentration & $\begin{array}{c}\text { Temperature } \\
\left({ }^{\circ} \mathrm{C}\right)\end{array}$ & $\begin{array}{c}\text { Result } 5 \mathrm{gg} \\
(\mathrm{mg} / \mathrm{kg})\end{array}$ & $\begin{array}{c}\text { Result } 0.5 \mathrm{~g} \\
(\mathrm{mg} / \mathrm{kg})\end{array}$ \\
\hline \multirow{2}{*}{$1 \mathrm{M}$} & 28 & 193 & 208 \\
\hline & 60 & 200 & 272 \\
\hline \multirow{2}{*}{$4 \mathrm{M}$} & 28 & 189 & 285 \\
\hline & 60 & 218 & 278 \\
\hline \multirow{2}{*}{$6 \mathrm{M}$} & 28 & 204 & 259 \\
\hline & 60 & 193 & 298 \\
\hline
\end{tabular}

reagents, including $\mathrm{HCl}$, and concluded that with $1 \mathrm{M} \mathrm{HCl}$ indium is leached over a period of less than 8 hours. These authors found approximately $260 \mathrm{mg}$ In per kg of glass. Savvilotidou et al. (2015) studied leaching using hydrochloric acid and water at a ratio of 3:2, obtaining a result of 317 mg In per $\mathrm{kg}$ of LCD at $80^{\circ} \mathrm{C}$. These results are comparabale to the findings of the present study.

The indium contents detected both in the present study and in studies conducted elsewhere are similar, being higher than the average contents found in ores ( 1 to $870 \mathrm{mg} / \mathrm{kg}$ when obtained from the processing of zinc minerals). This finding justifies the use of research resources and investment in technologies for the extraction of this mineral from secondary sources.

It should also be highlighted how in this study the monitors had been previously disassembled manually, and only the component (screen) containing indium was comminuted, in this way concentrating and thus facilitating detection of the element.

On an industrial scale the monitors would likely be comminuted whole, which would hamper the concentration and extraction of indium, thus rendering the process more complex, involving more process steps and adding to the costs.

\section{CONCLUSIONS}

Following manual disassembly, monitors were found to be constituted largely by polymers, printed circuit boards and the screen, representing an average of $10 \%$ of total weight of a monitor.

FRX analysis revealed how the glass used in LCD screens contained standard components of glasses, in addition to indium, in the form of the ITO layer.

In leaching tests, the best condition was obtained using hydrochloric acid $6 \mathrm{M}, 60^{\circ} \mathrm{C}$, with $298 \mathrm{mg} \mathrm{ln} / \mathrm{kg}$. However, other conditions should also be taken into account due to the finding of largely comparable results using lower acid concentrations.

Further studies are currently being carried out using different leaching agents, concentrations and temperatures in order to enhance technical comparison and shape future economic design.

\section{AKNOWLEDGEMENTS}

The authors wish to thank CAPES and CNPq for their financial support.

\section{REFERENCES}

Bernardes A.M. and Veit H.M. (2015) Electronic Waste - Recycling Techniques. 1. ed. Springer v. 1. $158 \mathrm{p}$.

Chou W.L., Huang, Y.H. (2009) Electrochemical removal of indium ions from aqueous solution using iron electrodes. Journal of Hazardous Materials 172, 46-53.

Dias P., Schmidt L., Gomes L.B., Bettanin A., Veit H., Bernardes A.M. (2018) Recycling Waste Crystalline Silicon Photovoltaic Modules by Electrostatic Separation. Journal of Sustainable Metallurgy. Volume 4, Issue 2, pp 176-186.

Fisher M., Kingsbury, T., Headley, L. (2004). Sustainable electrical and electronic plastics recycling. In: Proceeding on 2004, International Symposium on Electronics and the Environment, 10-13th May, Scottsdale, Arizona, USA.

Gabriel A.P., Santana R.M.C., Veit H.M. (2014) Evaluation of Recycled Polymers From CRT Monitor Frames of Different Years of Manufacture. Progress in Rubber, Plastics and Recycling Technology, Vol. 30, No. 1.

Gramatyka P., Nowosielski R., Sakiewicz P. (2007) Recycling of waste electrical and electronic equipment. Journal of Achievements in Materials and Manufacturing Engineering. Vol 20. Issues 1-2.

Juchneski N.C., Scherer J, Grochau I.H, Veit H.M. (2013) Disassembly and characterization of liquid crystal screens. Waste Management \& Research. 31(6):549-58.

Li J., Gao A.S., Dua H., Liu L. (2009) Recovery of valuable materials from waste liquid crystal display panel. Waste Management, 29 2033-2039.

Ruiz M. del C., Rodriguez M. H., Perino E., Olsina R. A..(2004) X-ray fluorescence analytical methodology for the determination of $\mathrm{Nb}, \mathrm{Ta}$, Fe and Mn extracted in hydrometallurgic processes. Lat. Am. appl. res. v.34 n.1 Bahía Blanca ene.

Schaik A.V., Reuter M.A. (2010) Dynamic modelling of E-waste recycling system performance based on product design. Minerals Engineering, 23, 192-210.

Savvilotidou V.,Hahladakis J.N., Gidarakos E. (2015) Leaching capacity of metals-metalloids and recovery of valuable materials from waste LCDs. Waste Management 45 314-324.

Swain, B., Mishra, C., Hong, H.S., Cho, S.S., 2016. Beneficiation and recovery of indium from liquid-crystal-display glass by hydrometallurgy. Waste Management. 57, 207-214.

Virolainen S., Ibana D., Paatero E. (2011) Recovery of indium from indium tin oxide by solvent extraction. Hydrometallurgy 107 No 1-2. $56-61$.

Wang X., Lu X., \& Zhang S. (2013). Study on the waste liquid crystal display treatment: Focus on the resource Recovery. Journal of Hazardous Materials 244- 245; 342-347.

Yang J., Retegan T. \& Ekberg C. (2013) Indium recovery from discarded LCD panel glass by solvent extraction. Hydrometallurgy 137. 